\title{
Short Communication: Wildlife species used as traditional medicine by local people in Indonesia
}

\author{
ANI MARDIASTUTI", BURHANUDDIN MASY'UD, LIN N. GINOGA, HAFIYYAN SASTRANEGARA, \\ SUTOPO
}

Department of Forest Resources and Ecotourism, Faculty of Forestry and Environment, Institut Pertanian Bogor. J1. Raya Dramaga, Kampus IPB Dramaga Bogor, 16680, West Java, Indonesia. Tel./fax.: +62-251-8621947, `email: aniipb@ indo.net.id.

Manuscript received: 6 December 2020. Revision accepted: 24 December 2020.

\begin{abstract}
Mardiastuti A, Masy'ud B, Ginoga LN, Sastranegara H, Sutopo. 2021. Short Communication: Wildlife species used as traditional medicine by local people in Indonesia. Biodiversitas 22: 329-337. Since a long time ago, wild animals (wildlife species) have been used by the local people as traditional medicine. Research has been conducted in some areas, but there was no study that incorporates all data. The objective of this research was to collect nation-wide information on the wildlife species (mammals, birds, reptiles, amphibians) used as traditional medicine, identify the species used the most, and collect information on the diseases that were believed can be cured by the wildlife species. Papers and reports from previous studies were collected and analyzed. Based on 55 published scientific papers, 114 wildlife species were known to be used by the local people as traditional medicine (59 species of mammals, 12 birds, 37 reptiles, 6 amphibians). Reptiles were used more intensively and believed may cure many diseases, mainly respiratory, digestive, skin, and musculoskeletal diseases. Among all species, Reticulated Python (Malayopython reticulatus), Common Water Monitor (Varanus salvator), Tokay Gecko (Gekko gecko), Common Sun Skink (Eutropis multifasciata), and Malayan Porcupine (Hystrix brachyura) were listed as the most popular species for traditional medicine. As some species have already listed as protected and endangered, a necessary precautionary program is needed to ensure the harvest sustainability and survival of the endangered species.
\end{abstract}

Keywords: Ethnomedicine, local knowledge, reptiles, VOSviewer, wildlife utilization

\section{INTRODUCTION}

Wildlife species (including their body parts and derived products) have been popularly used as a source of traditional medicine in Indonesia and in many other parts of the world, including in Brazil (Alves and Alves 2011, Barros et al. 2012), Argentina (Hernandez et al. 2015), Mexico (Jacob-Salcedo 2011), Nigeria (Ajagun et al. 2017), Ethiopia (Kendie et al. 2018), South Africa (Nieman et al. 2019), India (Jaroli et al. 2010, Borah and Prasad 2017), China (Still 2003), Korea (Kim and Song 2013), and the neighboring country of Malaysia (Halim et al. 2017). The use of wildlife species by the local people in Indonesia actually was not limited to traditional wildlife only. Many wildlife animals were also reported being used for consumption (Nijman 2016), as well as for traditional rituals and myths (Partasasmita et al. 2016). Food and medicine derived from wildlife have important nutritional values especially in times of crisis, although the wildlife food often regarded as supplementary to local peoples' diet (Alves et al. 2013).

The use of wildlife species as medicines and other purposes is part of local people's traditional knowledge. Traditional knowledge commonly refers to "the knowledge, innovations and practices of indigenous and local communities related to genetic resources, which has been developed through the experiences of communities over centuries, adapted to local needs, cultures and environments and passed down from generation to generation" (Ni 2011). Traditional knowledge is closely linked to ethnobiology, which can be grouped as ethnobotany and ethnozoology, based on the subject of interest.

Ethnozoology is defined as "the study seeks to understand how humans have perceived and interacted with faunal resources throughout history" (Alves and Souto 2011). Within the ethnozoology, there is a topic that discussed traditional medicine, also known as folk medicine, indigenous medicine, or ethnomedicine (Barros et al. 2012, Ajagun et al. 2017). Traditional medicine used in this paper refers to "the knowledge and practices used in the diagnosis, prevention and elimination of various sickness (either physical, mental or social imbalances) and relying on practical experience and observation that passing down from generation to generation" (Yuan et al. 2016).

Studies about the use of wildlife species by the local people were mostly carried out in small geographic areas, due to the nature of information collected through direct interviews. Until now there has been to attempt to incorporate all information on the national scale. The objective of this paper was to collect nation-wide information on the wildlife species used as traditional medicine, identify the species used the most, and collect information on the diseases that were believed can be cured by the wildlife species. The taxa that will be analyzed in this paper were focused on wild mammals, birds, reptiles, and amphibians only. Fish and domesticated species were excluded. 


\section{MATERIALS AND METHODS}

\section{Study area}

The study area of this research was in the Indonesian archipelago, a mega biodiversity hotspot, which was located in the tropical region $\left(6^{\circ} 08^{\prime} \mathrm{N}\right.$ to $11^{\circ} 15^{\prime} \mathrm{S}$ latitude and $94^{\circ} 45^{\prime} \mathrm{E}$ to $141^{\circ} 05^{\prime} \mathrm{E}$ longitude). Indonesia has 7 biogeographic regions from Sumatra, Java, Kalimantan, Sulawesi, Nusa Tenggara, Maluku, and Papua (Figure 1). These biogeographic regions comprise mountainous area with dense forests. There were also local people and ethnicities who live around the forests to exploit the resources to fulfill their daily needs. The notable ethnic who lives around the forests and exploit the local resources were Anak Dalam ethnic and Talang Mamak ethnic in Sumatra, Tengger ethnic and Osing ethnic in Java, Dayak ethnics in Kalimantan, Bada ethnic in Sulawesi, Sasak ethnic in Nusa Tenggara, Tobelo Dalam ethnic in Maluku, and Nduga ethnic in Papua.

\section{Data collection}

A comprehensive literature study was done by collecting all available journal articles, scientific reports, theses (doctoral, master's, and bachelor level), and books that contain information on ethnozoology in Indonesia. All publications were searched and accessed via internet, by using the keyword of "ethnobiology", "ethnozoology", "wildlife utilization", and some similar words in Indonesian language. If full publication is not available online, the articles were obtained through correspondence with the university librarian. Although there was no limitation of the published year, the results showed that the available literature were dated as far as 2001. Publications prior to that year might be available, but not posted in web.

There were 55 literature on ethnozoology in Indonesia, mostly $(80 \%)$ were written in Indonesian language, of which only 34 literature were related to ethnomedicine. This literature was not distributed evenly in the 7 biogeographic regions in Indonesia (Figure 1). Most data were from the western part of Indonesia (Oriental Realm): Java ( $\mathrm{n}=11$, e.g. Uyeda et al. (2014), Partasasmita et al. (2016)), followed by Sumatra ( $n=11$, e.g. Masy'ud et al. (2020)), and Kalimantan $(n=6)$. Very few data were reported from Nusa Tenggara $(n=1)$, Sulawesi $(n=1)$, and Maluku $(\mathrm{n}=1)$. Three other papers were across region.

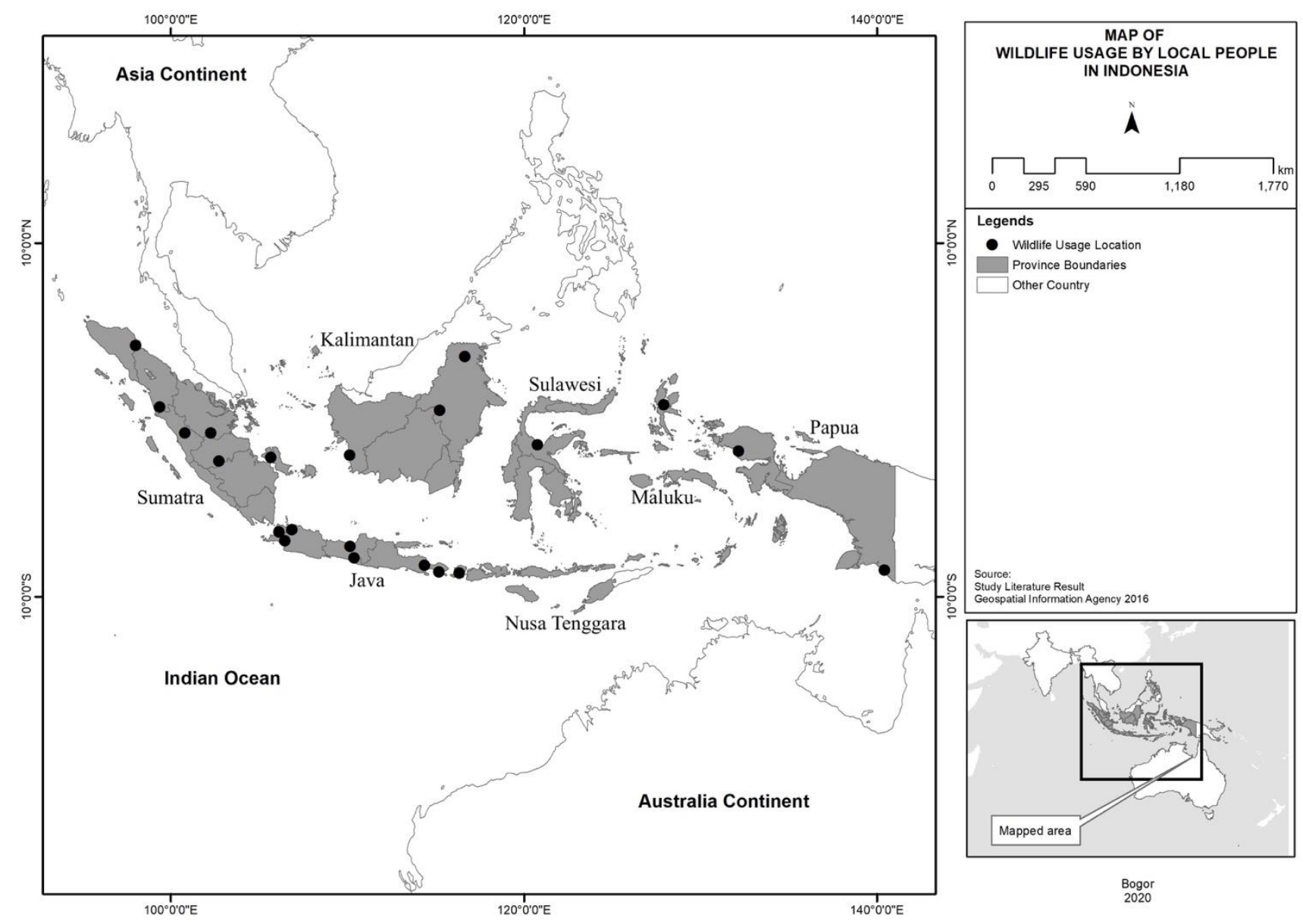

Figure 1. Location of wildlife uses by the local people in Indonesia 
The data were organized on a database and analyzed accordingly. The database contained location of the data collection, wildlife species, and its respective grouping, as well as the use of wildlife. Wildlife species were grouped based on their respective taxonomic grouping: amphibians (Anura), birds (Aves), mammals (Mammalia), and reptiles (Reptilia). Some taxa that were not able to be identified to species level, had to be identified at the genus level, making sure that there was no possible overlap with its corresponding species level. Number of wildlife species used by the local people was compared to the total number of its respective group in Indonesia. The total number of its respective group in Indonesia was referred to as the available wildlife checklist.

\section{Data analysis}

The data collected were analyzed by using Microsoft Excel (version 2019), Mendeley Desktop (version 1.19.4), and VOSviewer (version 1.6.16). VOSviewer was used to develop maps of collaboration based on co-occurrence type of analysis. VOSviewer is "a software tool for creating maps based on network data and for visualizing and exploring these maps", intended primarily for analyzing bibliometric data networks.

Data from all literature were extracted and collated in a database. For each species mentioned in the literature, a Relative Frequency of Citation (RFC) was estimated, by calculating the total number of references that mentioned the species of interest divided by the total number of papers being used for analysis.

\section{RESULTS AND DISCUSSION}

\section{The medicinal wildlife species}

There were 305 wildlife species that have been used by the local people for various purposes, of which 114 species $(37.4 \%)$ were used as traditional medicines. Based on the main taxa, the number of mammal species was rank first (in terms of species diversity and percentage of all species), followed by reptiles (Table 1). This result was similar to the percentage of medicinal animals used in other countries/ regions, e.g., Brazilian Amazon (Barros et al. 2012), Oyo State in South-western Nigeria (Ajagun et al. 2017), and Northwestern Ethiopia (Kendie et al. 2018). As for amphibians and birds, the diversity of amphibians being used was lower (i.e., only 6 species) than birds, but the percentage was still higher than birds. It was allegedly because the local people were better known for birds than reptiles.

Tabel 1. Number of wildlife species being used as traditional medicine based on major taxa

\begin{tabular}{llll}
\hline Taxa & $\begin{array}{c}\text { Number of } \\
\text { species being } \\
\text { used }\end{array}$ & $\begin{array}{c}\text { Total number of species in } \\
\text { Indonesia }\end{array}$ & $\begin{array}{c}\text { Percent- } \\
\text { age }\end{array}$ \\
\hline Mammals & 59 & 773 (Maryanto et al. 2019) & 7.6 \\
Birds & 12 & 1751 (Lepage 2020) & 0.7 \\
Reptiles & 37 & 755 (KLHK and LIPI 2019) & 4.9 \\
Amphibians 6 & 409 (KLHK and LIPI 2019) & 1.5 \\
Total & 114 & 3,688 & 3.09 \\
\hline
\end{tabular}

For mammals, surprisingly various groups were used by the local people as traditional medicine (Table 2), including large-sized mammals (such as ungulates and elephant), whales, primates, and small-sized mammals (such as rodents and treeshrews). Mammal species that was mentioned the most among the references, showed by a relatively high RFC, were Malayan Porcupine (Hystrix brachyura). Outside Indonesia, the Malayan Porcupine has been reported to have high value for medicinal values for their bezoar in the neighboring country of Malaysia (Tan et al. 2019) and Singapore (Heinricha et al. 2020).

Other mammalian species frequently used by the local people were Sun Bear (Helarctos malayanus), Sunda Pangolin (Manis javanica), Flying Fox (Pteropus sp.), and Long-tailed Macaque (Macaca fascicularis). These species were commonly used elsewhere as traditional medicine. Sun Bear, specifically its bile, has been used in Traditional Chinese Medicine for thousands of years (Gomez et al. 2020). The meat, scales and body parts of Sunda Pangolin and other seven other pangolin species have been widely used as traditional medicine worldwide (Wang et al. 2020). Flying fox and other 166 species of bats has been subjected to hunting for medicine and consumption in Asia, Africa, Oceania, and some Central and South American countries (Mildenstein et al. 2016). Furthermore, worldwide survey by Alves et al. (2010) revealed that at least 101 species of primates (38 genera and 10 families) were used in traditional folk practices and in magic-religious rituals, including Long-tailed Macaque, mostly in Cambodia.

Network-visualization image generated from VOSviewer (Figure 2), however, showed that the most visible species in the image were actually reptiles. Although the number of reptiles used by local people was ranked the second, many reptile species had high RFC values, and displayed clearly in the VOSviewer mapping. This result showed that there were more references for reptile usability as traditional medicine than other species. It means that the people were more believed in reptiles as traditional medicine than other classes, especially snakes, as also reported by Alves et al. (2013) in Brazil.

Four reptile species were stand out among others, namely Reticulated Python (Malayopython reticulatus), Common Water Monitor (Varanus salvator), Tokay Gecko (Gekko gecko), and Common Sun Skink (Eutropis multifasciata). All of these species were relatively easy to get from the local people's premises. Relatively large-sized species might also be hunted for consumption, including Water Monitor and Reticulated Python. Furthermore, other species that were also popular to be used by the local people were Chinese Ratsnake (Ptyas korros), Indonesian Cobra (Naja sputatrix), King Cobra (Ophiophagus hannah), Common House Gecko (Hemidactylus frenatus), Flat-tailed House Gecko (Hemidactylus platyurus), Malayan Soft-shelled Turtle (Dogania subplana), and Asiatic Softshell Turtle (Amyda cartilaginea).

A quick glance at the remedy generated by reptile species (Table 3) indicated that the local people believe that reptiles, in general, were excellent as traditional medicine and able to cure various diseases. The use of reptiles for medicinal purposes has been commonly 
practiced in many parts of the world, not only in Indonesia. Global reviews on wildlife use by local people elsewhere revealed that at least 284 species of reptiles have been used as traditional medicine (Alves et al. 2013). Brazil has been reported to use herpetofauna quite intensively (Alves et al. 2013, Fernandes-Ferreira et al. 2013, Mendonça et al. 2014), so does India (Das 2015). As for birds (Table 4) and amphibians (Table 5), some species were reported to be used, but only by very few references.

\section{The diseases that can be cured by using wildlife species}

The local people of Indonesia believed that there was 13 type of diseases that can be cured by using wildlife species. These local people mostly used wildlife species to cure respiratory diseases (68 species), digestive diseases (47 species), skin diseases (46 species), and musculoskeletal diseases (33 species), as shown in Figure 3 . Those diseases were mostly involved mammal and reptile species, including respiratory diseases (36 species of mammals, 23 reptiles), digestive diseases (23 mammals and 15 reptiles), skin diseases (27 reptiles and 17 mammals), and musculoskeletal diseases (16 reptiles and 12 mammals). Outside Indonesia, mammals and reptiles as traditional medicine were also common to use in other countries such as Tanzania (Vats and Thomas 2015), South Africa (Nieman et al. 2019), and Brazil (Teixeira et al. 2020).

Based on RFC value, some reptiles have higher values, which means the diseases that can be cured by using reptiles were more diverse than other species. King Cobra was the species with the highest number of diseases (9 diseases) that can be cured by using this species (see Table 3 ). This species mostly was used to cure skin diseases such as eczema, skin allergies, and scab. Other popular species to cure diseases were Reticulated Python, Common Water Monitor, and Tokay Gecko

The use of wildlife species, although in a subsistence basis, may raise some concerns on the conservation and harvest sustainability, as also noted by other researchers (e.g., Alves and Souto (2011), Ferreira et al. (2012)). Some species, mainly large mammals, are already protected by Indonesian law due to their rarity and their internationally threatened status. As the local people live in remote areas without any sufficient information exchanges, the local people might do not aware that the wildlife species they captured were protected by Indonesian law. Therefore, cautions need to be taken for several species that already threatened extinction.

In conclusion, the local people in Indonesia use many wildlife species from their environment, mostly reptiles, and mammals, as traditional medicines. The high number of species being used (114 species) indicated that wildlife species played important roles in traditional medicine and to maintain health of the local people. As some species (mostly mammals) have already listed as protected and endangered species, some necessary precautionary programs would be needed to ensure the harvest sustainability and survival of the endangered species.

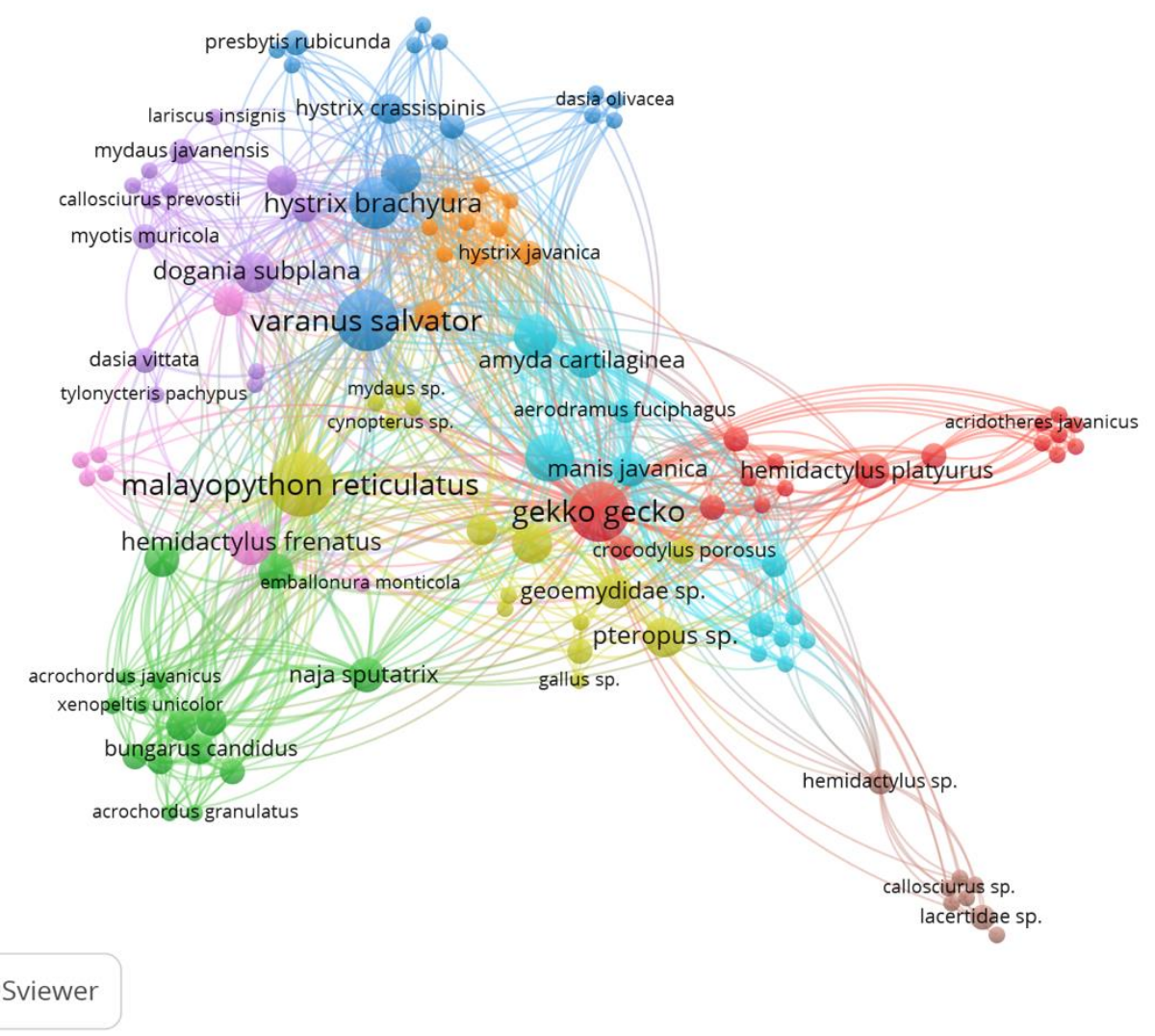

Figure 2. Network-visualization map of wildlife species being used as traditional medicine in Indonesia (114 species; 11 clusters; 1024 links) 


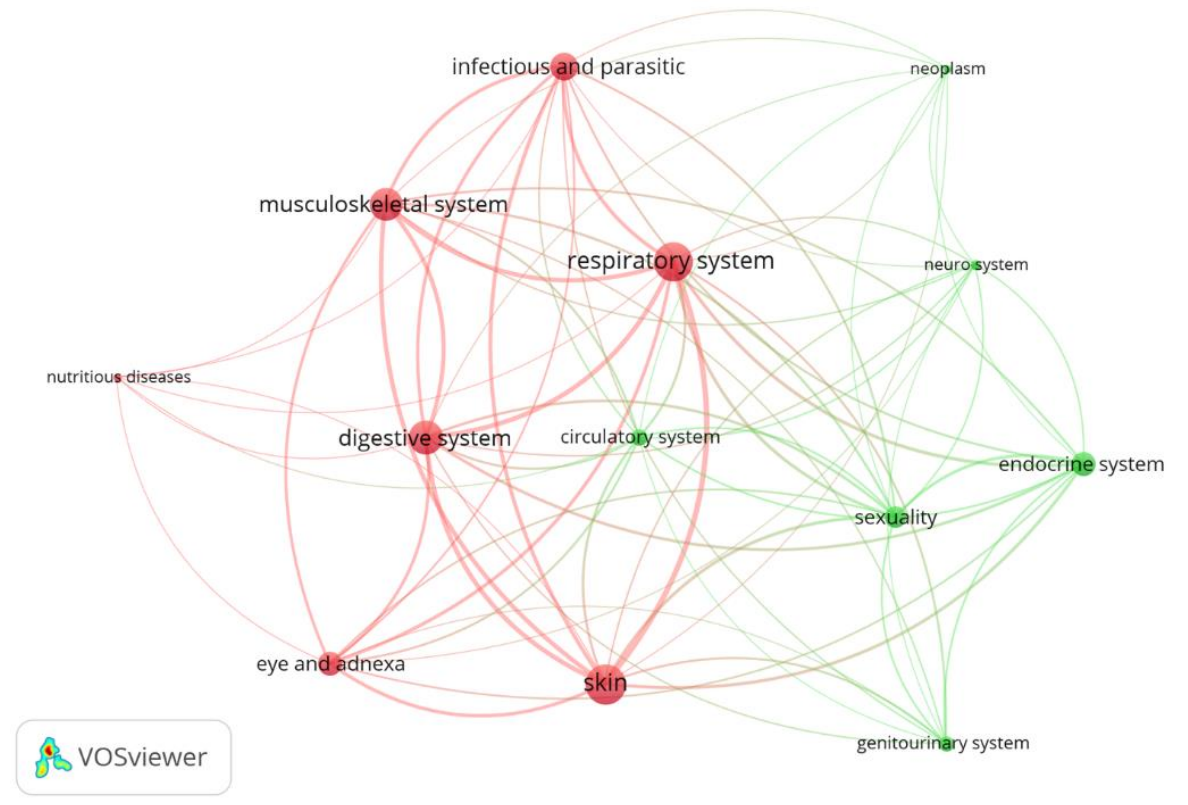

Figure 3. Network-visualization map of diseases that can be cured by using wildlife species (13 diseases; 2 clusters; 71 links)

Table 2. Mammal species used by the local people in Indonesia as traditional medicine and their traditional remedy

\begin{tabular}{|c|c|c|c|c|c|c|c|c|c|c|c|c|c|c|}
\hline Species & 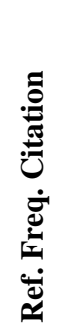 & 清 & 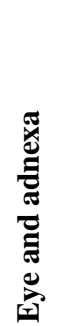 & 离 & 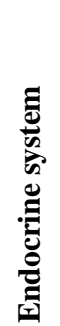 & 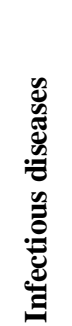 & 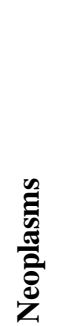 & 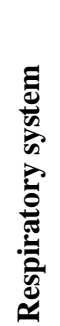 & 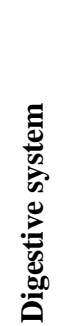 & 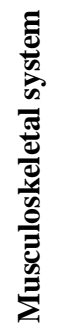 & 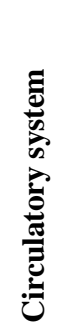 & 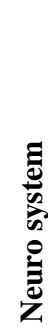 & 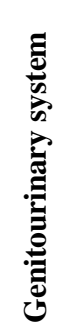 & 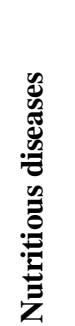 \\
\hline
\end{tabular}

Even-toed Ungulates

Sumatran Serow Capricornis sumatraensis

Bawean Deer Axis kuhlii

Indian Muntjac Muntiacus muntjak

Javan Rusa Rusa timorensis

Sambar Deer Rusa unicolor

Babirusa Babyrousa babyrussa

Bornean Bearded Pig Sus barbatus

Celebes Warty Pig Sus celebensis

Wild Boar Sus scrofa

Boar Sus sp.

Mouse-Deer Tragulus sp.

\section{Carnivore}

Sumatran Tiger Panthera tigris sumatrae

Sunda Stink Badger Mydaus javanensis

Stink Badger Mydaus sp.

Small-clawed Otter Aonyx cinereus

Sun Bear Helarctos malayanus

Asian Palm Civet Paradoxurus hermaphroditus

Whales

Fin Whale Balaenoptera physalus
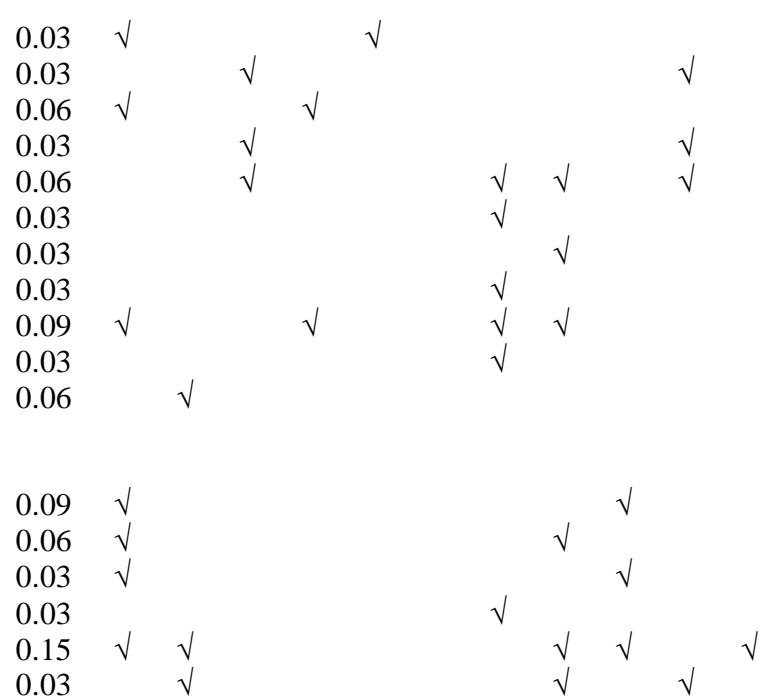

$0.03 \sqrt{ }$ 
Bats

Lesser Sheath-tailed Bat Emballonura monticola 0.03

Fruit Bat Cynopterus sp. $\quad 0.03$

Fruit Bat Pteropodidae sp. $\quad 0.03$

Admiralty Flying Fox Pteropus admiralitatum $\quad 0.03$

Black Flying Fox Pteropus alecto $\quad 0.03$

Flying Fox Pteropus sp. $\quad 0.15$

Large Flying Fox Pteropus vampyrus $\quad 0.06$

Least Horseshoe Bat Rhinolophus pusillus $\quad 0.03$

Whiskered Myotis Myotis muricola 0.06

Lesser Bamboo Bat Tylonycteris pachypus $\quad 0.03$

Cuscuses

Moluccan Cuscus Phalanger ornatus 0.03

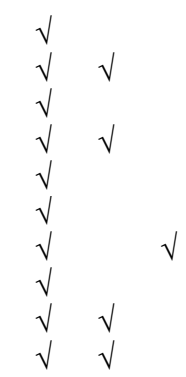

Rabbit and Hares

Rabbit Leporidae sp.

Indian Hare Lepus nigricollis

Hare Lepus sp.

0.03

0.03

0.06

Odd-toed Ungulates

Sumatran Rhinoceros Dicerorhinus sumatrensis

Javan Rhinoceros Rhinoceros sondaicus

$0.03 \sqrt{ }$

$0.03 \sqrt{ }$

Pangolin

Sunda Pangolin Manis javanica

$0.12 \sqrt{ }$

Primates

Long-tailed Macaque Macaca fascicularis

Celebes Crested Macaque Macaca nigra

Macaque Macaca sp.

Tonkean Macaque Macaca tonkeana

White-fronted Surili Presbytis frontata

Maroon Leaf Monkey Presbytis rubicunda

Javan Lutung Trachypithecus auratus

Sunda Slow Loris Nycticebus coucang

Elephant

Sumatran Elephant Elephas maximus sumatranus

0.03

Rodents

Malayan Porcupine Hystrix brachyura

Thick-spined Porcupine Hystrix crassispinis

Sunda Porcupine Hystrix javanica

Sumatran Porcupine Hystrix sumatrae

Long-tailed Porcupine Trichys fasciculata

House Mouse Mus musculus

Rice-field Rat Rattus argentiventer

Rat Rattus sp.

Plantain Squirrel Callosciurus notatus

Prevost's Squirrel Callosciurus prevostii

Squirrel Callosciurus sp.

Three-striped Ground Squirrel Lariscus insignis

0.18 V

$0.03 \sqrt{ }$

$0.03 \sqrt{ }$

0.03

0.03

0.06

0.06

$0.03 \sqrt{ }$

0.24

0.09

0.06

0.09

0.03

0.06

0.03

0.15

0.03

0.03

0.03

0.03

$\sqrt{ }$

$\sqrt{2}$

Treeshrews

Horsfield's Treeshrew Tupaia javanica

0.06

Pygmy Treeshrew Tupaia minor

Treeshrew Tupaia sp.

Total species of each remedy category

0.03
0.09

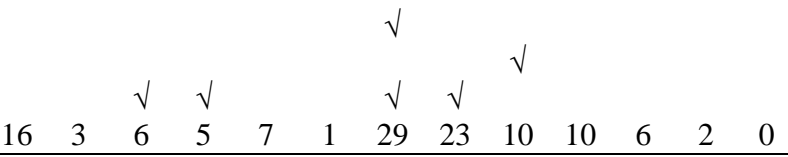


Table 3. Reptile species used by the local people in Indonesia as traditional medicine and their traditional remedy

Species

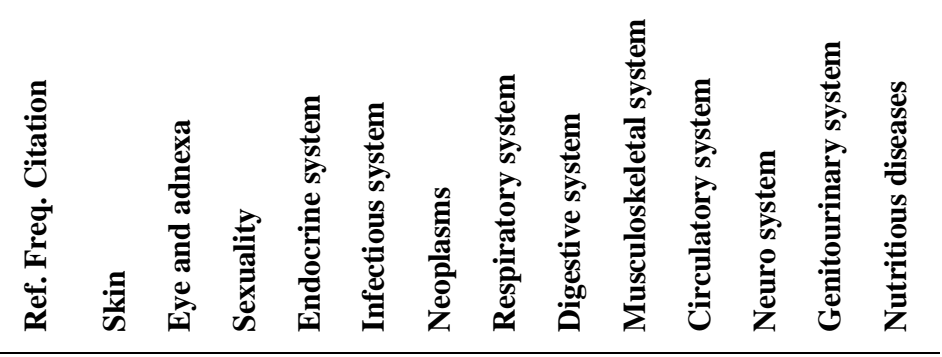

Snakes

Little File Snake Acrochordus granulatus

Javan File Snake Acrochordus javanicus

Gold-ringed Cat Snake Boiga dendrophila

Radiated Ratsnake Coelognathus radiatus

Chinese Ratsnake Ptyas korros

Oriental Ratsnake Ptyas mucosus

Blue Krait Bungarus candidus

Banded Krait Bungarus fasciatus

Elapid Snake Elapidae sp.

Spitting Cobras Naja sp.

Indonesian Cobra Naja sputatrix

Equatorial Spitting Cobra Naja sumatrana

King Cobra Ophiophagus hannah

Linne's Water Snake Homalopsis buccata

Sumatra Python Python curtus

Reticulated Python Malayopython reticulatus

Malayan Pit Viper Calloselasma rhodostoma

Pit Viper Snakes Trimeresurus sp.

Sunbeam Snake Xenopeltis unicolor

$\begin{array}{lllll}0.03 & & \sqrt{ } & & \\ 0.03 & \sqrt{ } & & & \\ 0.06 & \sqrt{ } & \sqrt{ } & & \\ 0.09 & \sqrt{ } & \sqrt{ } & \sqrt{ } & \sqrt{ } \\ 0.12 & \sqrt{ } & \sqrt{ } & \sqrt{ } & \sqrt{ } \\ 0.03 & \sqrt{ } & & & \\ 0.09 & \sqrt{ } & \sqrt{ } & \sqrt{ } & \sqrt{ } \\ 0.09 & \sqrt{ } & \sqrt{ } & \sqrt{ } & \sqrt{ } \\ 0.03 & \sqrt{ } & & & \\ 0.03 & \sqrt{ } & & & \sqrt{ } \\ 0.12 & \sqrt{ } & \sqrt{ } & \sqrt{ } & \sqrt{ } \\ 0.03 & & & & \\ 0.12 & \sqrt{ } & \sqrt{ } & \sqrt{ } & \sqrt{ } \\ 0.06 & \sqrt{ } & \sqrt{ } & & \\ 0.03 & & & & \\ 0.38 & \sqrt{ } & \sqrt{ } & \sqrt{ } & \sqrt{ } \\ 0.06 & \sqrt{ } & \sqrt{ } & \sqrt{ } & \sqrt{ } \\ 0.03 & \sqrt{ } & \sqrt{ } & & \\ 0.03 & \sqrt{ } & & & \end{array}$

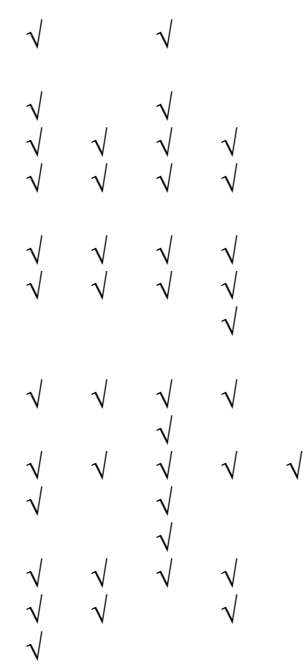

Lizards and monitors

Common Flying Dragon Draco volans

Tokay Gecko Gekko gecko

Common House Gecko Hemidactylus frenatus

Flat-tailed House Gecko Hemidactylus platyurus

House Gecko Hemidactylus sp.

Lizards Lacertidae sp.

Asian Grass Lizard Takydromus sexlineatus

Borneo Skink Dasia vittata

Olive Tree Skink Dasia olivacea

Common Sun Skink Eutropis multifasciata

Skink Lizard Eutropis sp.

Common Water Monitor Varanus salvator

0.03

0.32

0.18
0.12

0.12
0.06

0.06 v

$0.06 \sqrt{ }$

$0.03 \sqrt{ }$

0.06

0.03

0.21

0.03

0.35

Turtles and tortoises

Turtles Geoemydidae sp.

Tortoises Testudo sp.

0.12

0.03

Brown Tortoise Manouria emys

Asiatic Softshell Turtle Amyda cartilaginea

Malayan Soft-shelled Turtle Dogania subplana

0.03

0.12

0.15

$\sqrt{ }$
$\sqrt{ }$
$\sqrt{ }$
$\sqrt{ }$
$\sqrt{ }$
$\sqrt{ }$
$\sqrt{ }$
$\sqrt{ }$
$V$

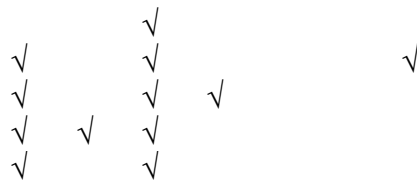

Crocodiles

Saltwater Crocodile Crocodylus porosus

0.06

Total species of each remedy category

$\begin{array}{lllllllll}28 & 14 & 14 & 10 & 8 & 1 & 23 & 15\end{array}$

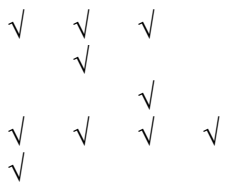


Table 4. Bird species used by the local people in Indonesia as traditional medicine and their traditional remedy

Species

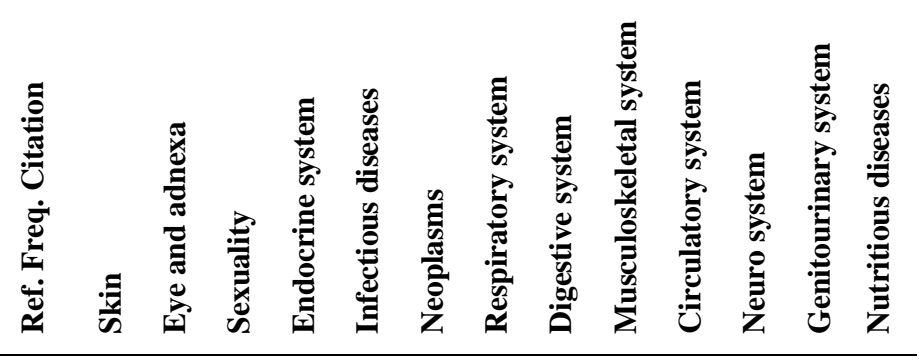

Swiftlet

Edible-nest Swiftlet Aerodramus fuciphagus

0.06

Pigeon

Pigeon Columbidae sp.

Hornbill

Helmeted Hornbill Rhinoplax vigil

0.03

Cuckoo

Short-toed Coucal Centropus rectunguis

0.03

0.03

Black Eagle Ictinaetus malayensis

Junglefowls

Red Junglefowl Gallus gallus

Junglefowl Gallus sp.

Wild Turkey Meleagris sp.

0.03

0.03

0.03

Passerines

Crow Corvus sp.

Eurasian Tree Sparrow Passer montanus

0.03

0.03

White-vented Myna Acridotheres javanicus

0.03

Owl

Wood Owl Strix sp.

Total species of each remedy category

0.03

\begin{tabular}{lllllllllllll}
0 & 3 & 0 & 0 & 1 & 0 & 5 & 2 & 2 & 1 & 0 & 0 & 1 \\
\hline
\end{tabular}

Table 5. Amphibian species used by the local people in Indonesia as traditional medicine and their traditional remedy

\begin{tabular}{|c|c|c|c|c|c|c|c|c|c|c|c|c|c|c|}
\hline Species & 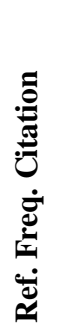 & 滰 & 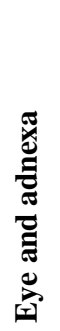 & 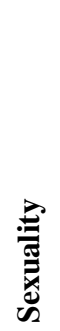 & 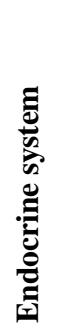 & 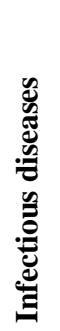 & 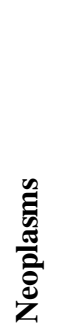 & 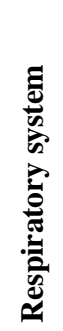 & 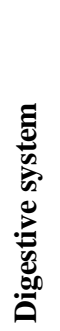 & 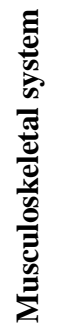 & 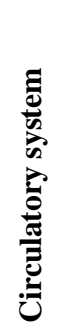 & 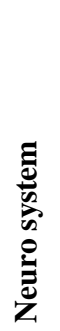 & 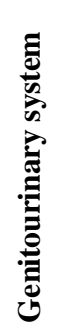 & 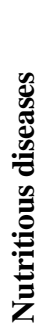 \\
\hline \multicolumn{15}{|l|}{ Toads } \\
\hline Toad Bufo sp. & 0.06 & $\sqrt{ }$ & & $\sqrt{ }$ & & & & $\sqrt{ }$ & & & & & & \\
\hline Asian Common Toad Duttaphrynus melanostictus & 0.03 & & & & & & & & $\sqrt{ }$ & & & & & \\
\hline \multicolumn{15}{|l|}{ Frogs } \\
\hline Long-tailed Frog Fejervarya cancrivora & 0.03 & & & & & & & $\sqrt{ }$ & & $\sqrt{ }$ & & & & \\
\hline Java Frog Occidozyga sp. & 0.03 & & & & & & & & & $\sqrt{ }$ & & & & \\
\hline Common Green Frog Hylarana erythraea & 0.03 & $\sqrt{ }$ & & & & & & & & & & & & \\
\hline Pond Frog Rana sp. & 0.03 & & & & & & & & $\sqrt{ }$ & & & & & \\
\hline Total species of each remedy category & & 2 & 0 & 1 & 0 & 0 & 0 & 2 & 2 & 2 & 0 & 0 & 0 & 0 \\
\hline
\end{tabular}




\section{ACKNOWLEDGEMENTS}

Funding for this research was provided by the Ministry of Research and Technology/National Research and Innovation Agency (Ristek-BRIN; the Government of Indonesia) through IPB University, under the scheme of Penelitian Dasar Unggulan Perguruan Tinggi (PDUPT); contract number 4004/IT3.L1/PN/2020 and 2519/IT3.L1/PN/2020, fiscal year 2020.

\section{REFERENCES}

Ajagun EJ, Anyaku CE, Afolayan MP. 2017. A survey of the traditional medical and non-medical uses of animals species and parts of the indigenous people of Ogbomoso, Oyo State. International Journal of Herbal Medicine 5 (3): 26-32.

Alves RRN, Souto WMS, Barboza RRD. 2010. Primates in traditional folk medicine: a world overview. Mammal Rev. 40 (2): 155-180.

Alves RRN, Alves HN. 2011. The faunal drugstore: animal-based remedies used in traditional medicines in Latin America. Journal of Ethnobiology and Ethnomedicine 7 (9).

Alves RRN, Souto WMS. 2011. Ethnozoology in Brazil: current status and perspectives. J. Ethnobiol. Ethnomed. 7: 22

Alves RRN, Oliveira TPR, Rosa IL. 2013. Wild animals used as food medicine in Brazil. Evidence-Based Complementary and Alternative Medicine 670352. 12pp. http://dx.doi.org/10.1155/2013/670352.

Barros FB, Varela SAM, Pereira HM, Vicente L. 2012. Medicinal use of fauna by a traditional community in the Brazilian Amazonia. Journal of Ethnobiology and Ethnomedicine 8: 37. DOI: 10.1186/1746-4269 8-37

Borah MP, Prasad SB. 2017. Ethnozoological study of animals based medicine used by traditional healers and indigenous inhabitants in the adjoining areas of Gibbon Wildlife Sanctuary, Assam, India. Journal of Ethnobiology and Ethnomedicine 13: 39. DOI: 10.1186/s13002 017-0167-6.

Das D. 2015. Ethnozoological practices among tribal inhabitants in Khowai District of Tripura, North-East India. J. Glob. Biosci. 4 (9) 3364-3372. ISSN: 2320-1355.

Fernandes-Ferreira H, Mendonca SV, Cruz RL, Borges-Nojosa DM, Alves RRN. 2013. Hunting of herpetofauna in montane, coastal, and dryland areas of northeastern Brazil. Herpetol. Conserv. Biol. 8 (3): 652-666.

Ferreira FS, Albuquerque UP, Coutinho HDM, Almeida WO, Alves RRN 2012. The trade in medicinal animals in northeastern Brazil. Evidence-Based Complementary and Alternative Medicine 126938 $20 \mathrm{pp}$.

Gomez L, Shepherd CR, Khoo MS. 2020. Illegal trade of sun bear parts in the Malaysian states of Sabah and Sarawak. Endangered Species Research 41: 279-287. https://doi.org/10.3354/esr01028.

Halim MASA, Salleh HS, Mohamed WN, Mat NHN, Yusof Y. 2017 Malaysian traditional medicine: the usage of marine resources as a treatment and complementary medicine for heart disease. Journal of $\begin{array}{llll}\text { Fundamental and Applied Science } 9 \text { (6S): 816-827. } & \end{array}$ http://dx.doi.org/10.4314/jfas.v9i6s.61.

Heinricha S, Toomesa A, Gomez L. 2020. Valuable stones: the trade in porcupine bezoars. Global Ecology and Conservation 24: e01204 DOI: $10.106 /$ j.gecco.2020.e01204.

Hernandez J, Campos CM, Borghi CE. 2015. Medicinal use of wild fauna by mestizo communities living near San Guillermo Biosphere Reserve (San Juan, Argentina). Journal of Ethnobiology and Ethnomedicine 11: 15

Jacob-Salcedo MR, Alonso-Castro AJ, Zarate-Martinez A. 2011. Folk medicinal use of fauna in Mapimi, Durango, México. J. Ethnopharmacol. 133: 902-906.

Jaroli DP, Mahawar MM, Vyas N. 2010. An ethnozoological study in the adjoining areas of mount Abu Wildlife Sanctuary, India. J. Ethnobiol. Ethnomed. 6: 1-9.
[KLHK] Kementerian Lingkungan Hidup dan Kehutanan, [LIPI] Lembaga Ilmu Pengetahuan Indonesia. 2019. Panduan Identifikasi Jenis Satwa Liar Dilindungi: Herpetofauna. Kementerian Lingkungan Hidup dan Kehutanan, Jakarta.

Kendie FA, Mekuriaw SA, Dagnew MA. 2018. Ethnozoological study of traditional medicine appreciation of animals and their products among the indigenous people of Metema Woreda, North-Western Ethiopia. Journal of Ethnobiology and Ethnomedicine 14: 37. https://doi.org/10.1186/s13002-018-0234-7.

Kim H, Song MJ. 2013. Ethnozoological study of medicinal animals on Jeju Island, Korea. Journal of Ethnopharmacology 146 (1): 75-82. DOI: 10.1016/j.jep.2012.11.011.

Lepage D. 2020. Checklist of the birds of Indonesia. Avibase, the world bird database. https://avibase.bsceoc.org/checklist.jsp?lang=EN\&region=id\&list=clements\&format=1.

Maryanto I, Maharadatunkamsi, Achmadi AS, Wiantoro S, Sulityadi E, Yoneda M, Suyanto A, Sugardjito J. 2019. CHECKLIST OF THE MAMMALS OF INDONESIA: Scientific, English, Indonesian Name, and Distribution Area Table in Indonesia Including CITES, IUCN and Indonesian Category for Conservation. Lembaga Ilmu Pengetahuan Indonesia, Bogor.

Masy'ud B, Felayati NR, Sunarminto T. 2020. Local wisdom in animal conservation and animal use as medicine of Orang Rimba in Bukit Duabelas National Park, Jambi. Jurnal Manajemen Hutan Tropika 26 (1): 72-79. DOI: 10.7226/jtfm.26.1.72.

Mendonça LET, Vieira WLS, Alves RRN. 2014. Caatinga ethnoherpetology: relationship between herpetofauna and people in a semiarid region of northeastern Brazil. Amphib. Reptile Conserv. 8 (1): 24-32.

Mildenstein T, Tanshi I, Racey PA. 2016. Exploitation of bats for bushmeat and medicine. In: Voigt CC, Kingston T (eds) Bats in the Anthropocene: Conservation of Bats in a Changing World. Springer International Publishing AG, Switzerland. DOI: 10.1007/978-3-31925220-9_12.

Ni KJ. 2011. Traditional knowledge and global lawmaking. Northwestern Journal of International Human Rights 10 (2): 3.

Nieman WA, Leslie AJ, Wilkinson A. 2019. Traditional medicinal animal use by Xhosa and Sotho communities in the Western Cape Province, South Africa. Journal of Ethnobiology and Ethnomedicine 15: 34. https://doi.org/10.1186/s13002-019-0311-6.

Nijman V. 2016. Perceptions of Sundanese Men towards the Consumption of Water Monitor Lizard Meat in West Java, Indonesia. Biawak 10(1):22-25.

Partasasmita R, Iskandar J, Malone N. 2016. Karangwangi's people (South Cianjur, West Java, Indonesia) local knowledge of species, forest utilization, and wildlife conservation. Biodiversitas 17(1):154-161. doi: 10.13057/biodiv/d170123.

Still J. 2003. Use of animal products in traditional Chinese medicine: environmental impact and health hazards. Complement Ther. Med. 11: 118-122.

Tan CS, Ng AH, Loh YC, Yam MF. 2019. A traditional folk medicine in Malaysia: porcupine bezoar. Oriental Pharmacy and Experimental Medicine. https://doi.org/10.1007/s13596-019-00370-4.

Teixeira JVS, Santos JS, Guanaes DHA, Rocha WD, Schiavetti A. 2020. Uses of wild vertebrates in traditional medicine by farmers in the region surrounding the Serra do Conduru State Park (Bahia, Brazil). Biota Neotropica 20 (1): e20190793. http://dx.doi.org/10.1590/16760611-BN-2019-0793.

Uyeda L, Iskandar E, Purbatrapsila A, Pamungkas J, Wirsing A, Kyes R. 2014. Water monitor lizard (Varanus salvator) satay: a treatment for skin ailments in Muarabinuangeun and Cisiih, Indonesia. Biawak 8 (1): 35-38.

Vats R, Thomas S. 2015. A study on use of animals as traditional medicine by Sukuma Tribe of Busega District in North-western Tanzania. Journal of Ethnobiology and Ethnomedicine 11: 38. DOI: 10.1186/s13002-015-0001-y.

Wang Y, Turvey ST, Leader-Williams N. 2020. Knowledge and attitudes about the use of pangolin scale products in Traditional Chinese Medicine (TCM) within China. People and Nature 2: 903-912.

Yuan H, Ma Q, Ye L, Piao G. 2016. The traditional medicine and modern medicine from natural products. Molecules 21: 559. DOI: 10.3390/molecules21050559. 